\title{
Article \\ The Preparation, Morphological Characterization and Possible Electroanalytical Application of a Hydroxyapatite-Modified Glassy Carbon Electrode
}

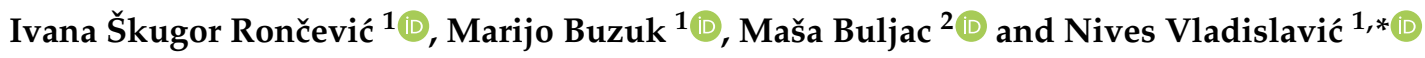 \\ 1 Department of General and Inorganic Chemistry, Faculty of Chemistry and Technology, University of Split, \\ 21000 Split, Croatia; skugor@ktf-split.hr (I.Š.R.); buzuk@ktf-split.hr (M.B.) \\ 2 Department of Environmental Chemistry, Faculty of Chemistry and Technology, University of Split, \\ 21000 Split, Croatia; masa@ktf-split.hr \\ * Correspondence: nives@ktf-split.hr
}

\section{check for} updates

Citation: Škugor Rončević, I.; Buzuk, M.; Buljac, M.; Vladislavić, N. The Preparation, Morphological Characterization and Possible Electroanalytical Application of a Hydroxyapatite-Modified Glassy Carbon Electrode. Crystals 2021, 11, 772. https://doi.org/10.3390/ cryst11070772

Academic Editors: Boris-Marko Kukovec and Marijana Đaković

Received: 31 May 2021

Accepted: 26 June 2021

Published: 1 July 2021

Publisher's Note: MDPI stays neutral with regard to jurisdictional claims in published maps and institutional affiliations.

Copyright: (c) 2021 by the authors. Licensee MDPI, Basel, Switzerland. This article is an open access article distributed under the terms and conditions of the Creative Commons Attribution (CC BY) license (https:/ / creativecommons.org/licenses/by/ $4.0 /)$.
Abstract: By simple modification of a GC electrode with biofunctional material, hydroxyapatite (HAp), an efficient electroanalytical tool, was designed and constructed. Modification of the GC surface includes two steps in synthesis: electrochemical deposition and chemical conversion. The properties, structure, and morphology of a nanosized material formed on a surface and absorbability were studied by electrochemical impedance spectroscopy, Fourier-transform infrared spectroscopy and scanning electron microscopy with energy-dispersive spectroscopy analysis. Numerous methods in this work confirmed that the developed method for controlled HAp deposition results in a HAp open structure and uniform morphology, which is capable of the selective absorption of the target species. The main goal of this study was the possibility of using a HAp-modified electrode for the fast screening of copper, cadmium, and lead content in honey and sugar samples. The electrochemical behavior and potential of the electroanalytical determination of heavy metals using the HAp/GC electrode were studied using cyclic voltammetry and square wave anodic stripping voltammetry. The HAp/GC electrode exhibited great performance in the determination of heavy metals, based on the reduction of target metals, because of the high absorbability of the HAp film and the electroanalytical properties of GC. A linear response between 10 and $1000 \mu \mathrm{g} / \mathrm{L}$ for $\mathrm{Cu}$ and $\mathrm{Pb}$ and 1 and $100 \mu \mathrm{g} / \mathrm{L}$ for $\mathrm{Cd}$, with an estimated detection limit of 2.0, 10.0, and $0.9 \mu \mathrm{g} / \mathrm{L}$, respectively, was obtained.

Keywords: hydroxyapatite; glassy carbon electrode; electroanalytical application; heavy metals; food analysis

\section{Introduction}

Environmental contamination is one of the main health problems in industrial countries [1]. Metal pollution has become an increasingly important ecological problem in developed and developing countries. Metal and metalloid pollution in the air, soil, and water comes from mining activities; industrial production; industrial wastes and wastewater; the engines of passenger cars, trucks, and off-road vehicles; areas used for the illegal disposal of hazardous waste; the burning of leaded gasoline, chemicals, and manure-based fertilizers; some pesticides; geological processes; plastic films containing metals, etc. Heavy metals in dust and gases can also enter soil and water by natural sedimentation, rainfall, or infiltration when released into the air [2]. Toxic metals can easily enter the food chain if contaminated water, soils, air, or plants are used for food production.

The term "heavy metals" refers to a metallic element that has a relatively high density and is toxic or poisonous even at low concentrations. Heavy metals include elements such as lead $(\mathrm{Pb})$, cadmium $(\mathrm{Cd})$, nickel $(\mathrm{Ni})$, iron $(\mathrm{Fe})$, zinc $(\mathrm{Zn})$, chromium $(\mathrm{Cr})$, and copper $(\mathrm{Cu})$. Some of them, such as $\mathrm{Cd}$, are exclusively toxic, whereas some are biogenic, such as $\mathrm{Cu}$ [3]. There are different sources of heavy metals in the environment such as natural, 
agricultural, industrial, domestic effluent, and atmospheric sources, as well as other sources. They are stable in the environment, difficult to eliminate, and cause irreversible damage to the survival, feeding, growth, and behavior of organisms. Activities such as mining and smelting operations and agriculture have contaminated extensive areas of the world, mostly by heavy metals such as $\mathrm{Cd}, \mathrm{Cu}$, and $\mathrm{Zn}$ [4]. Several authors have indicated that honeybees and honey can serve as environmental bioindicators for metal pollution, as biomarkers for the identification of botanical and geographical origins represent a honey fingerprint [5-7].

Honey bees can be exposed to heavy metals when foraging contaminated honey and pollen resources and, in some cases, by airborne exposure. Traditional analytical methods have been proposed for the detection and quantification of heavy metals in honey samples [8] such as flame atomic absorption spectrometry (FAAS) for $\mathrm{Ca}, \mathrm{Mg}$, and $\mathrm{Zn}$ [9]; atomic absorption spectrometry for $\mathrm{Pb}, \mathrm{Cd}$, and $\mathrm{Cu}[8,10]$; or inductively coupled plasma mass spectrometry to uncover metal content in honey samples [11-13]. However, some of the above-mentioned methods are nonspecific and laborious and needed harmful and expensive substances, which, in combination with a long sample preparation time and well-trained operators, drastically increased the time and cost of analysis. Thus, the development of different electroanalytical methodologies has been applied to explore metal contamination. Stripping voltammetric techniques are powerful analytical tools that are becoming widely used in various chemical analyses of food contaminants or essential elements, additive dyes, and other organic compounds of biological significance [14] such as anodic stripping voltammetry at $\mathrm{Hg}$ microelectrodes for the determination of $\mathrm{Cu}, \mathrm{Pb}, \mathrm{Cd}$, and $\mathrm{Zn}$ [15]; $\mathrm{Cd}$ and $\mathrm{Pb}$ at bismuth-film-modified glassy carbon electrodes using square wave anodic stripping voltammetry [16]; or $\mathrm{Zn}, \mathrm{Cd}, \mathrm{Pb}$, and $\mathrm{Cu}$ in raw propolis samples at pencil lead-bismuth film electrodes $[17,18]$. These are successively applied for the analysis of metals in honey samples.

In our previous research, we reported on the preparation of hydroxyapatite (HAp) coatings on a glass carbon electrode by electrochemical deposition combined with the chemical precipitation of $\mathrm{Ca} / \mathrm{P}$ phases and subsequent treatment in alkaline $(\mathrm{NaOH})$ solution (physical and chemical process). Thin HAP coatings formed on the surface of GC electrodes have excellent electroanalytical performance [19]. Hydroxyapatite $\left(\mathrm{Ca}_{10}\left(\mathrm{PO}_{4}\right)_{6}(\mathrm{OH})_{2}, \mathrm{HAp}\right)$ is a new type of bioceramic with great bioactivity and particular multiadsorbing sites analogous to the mineral components of bone and teeth. Due to its "open structure", great varieties of cationic and anionic substitutions in HAp are possible, including its application for electroanalytical purposes. Many different applications are reported in the literature, mostly in bioscience, because of its acid-base properties, ion-exchange ability, biocompatibility, and adsorption capacity [20-23].

The morphology of HAp coatings has been studied using Fourier-transform infrared spectroscopy (FTIR), scanning electron microscopy (SEM), and atomic force microscopy (AFM). The prepared film electrode has been used as a sensing material for the detection of heavy metals in honey and sugar. Additionally, for the preparation of real samples, a method for preparing natural organic materials has been developed.

Different approaches for the synthesis of $\mathrm{Ca} / \mathrm{P}$ phases are presented in the literature, including physical techniques (different performances of spraying, sputtering, evaporation, or deposition) and chemical methods (sol-gel, immersion coating, hot-isostatic pressing, electrophoretic deposition, electrochemical deposition, (micro)emulsion routes, dip coating, or sintering) [24-27]. Different ratios of the crystalline/amorphous phase of HAp coatings can be achieved due to the different methods of synthesis employed in the synthesis of HAp [28,29]. The chemical composition, structure, and property of the amorphous phase are dependent on the structure of its clusters. The formation of amorphous calcium phosphate and its subsequent transition to crystalline hydroxyapatite lead to the formation of a cluster structure [30] and the possible formation of a coordination complex of HAp and heavy metals.

Electrochemical deposition, an environmentally friendly method for coating formation, represents an ecologically clean and safe approach with unique advantages due to its 
ability to create a uniform coating on curved surfaces and other complex geometries. Additionally, the process is economically acceptable and simple, as it can be performed at room temperature, and the morphology of the coating can be easily controlled by changing the time and potential of precipitation, concentration, and $\mathrm{pH}$ of the electrolyte or by adding a growth guide [31,32].

The analytical performances of the electrochemical methods depending on the sensor's construction and some numerical data of the selected metals at HAp-modified electrodes are presented in Table 1. From the presented results for the detection limit, it can be seen that the electrochemical determination of heavy metals is comparable to the results achieved with flame atomic absorption spectroscopy (FAAS).

Table 1. Electroanalytical and analytical performances reported for the electrochemical determination of selected heavy metals at the HAp-modified electrode.

\begin{tabular}{|c|c|c|c|c|c|c|}
\hline Electrode Modification/Substrate & $\begin{array}{c}\text { Electroanalytical } \\
\text { Methods }\end{array}$ & Analytes & $\begin{array}{c}\text { Linear Range } \\
(\mu \mathrm{g} / \mathrm{L})\end{array}$ & Analyzed Samples & LOD $(\mu g / L)$ & Ref. \\
\hline $\mathrm{HAp}-\mathrm{CILE} / \mathrm{CP}^{1}$ & $\begin{array}{c}\text { CV } \\
\text { SWASV }\end{array}$ & $\begin{array}{l}\mathrm{Pb} \\
\mathrm{Cd}\end{array}$ & $0.11-0.121$ & Wastewater sample & $\begin{array}{l}0.041 \\
0.056\end{array}$ & 2009 [33] \\
\hline nHAp/ionophore/Nafion/GCE ${ }^{2}$ & $\begin{array}{c}\text { CV } \\
\text { ASDPV }\end{array}$ & $\mathrm{Pb}$ & 1 to 166 & Real water sample & 0.21 & $2009[34]$ \\
\hline CNT-HAp $/ \mathrm{GCE}^{3}$ & $\begin{array}{c}\text { CV } \\
\text { DPV }\end{array}$ & $\mathrm{Cd}$ & $2.25-33,723$ & $\begin{array}{c}\text { Real tap } \\
\text { water sample }\end{array}$ & 0.45 & $2009[35]$ \\
\hline $\mathrm{Bi} / \mathrm{HAp}-\mathrm{CME}^{4}$ & $\begin{array}{c}\text { CV } \\
\text { SWASV }\end{array}$ & $\begin{array}{l}\mathrm{Pb} \\
\mathrm{Cd}\end{array}$ & Up to 150 & $\begin{array}{c}\text { Spiked lake } \\
\text { water sample }\end{array}$ & $\begin{array}{l}5 \\
5\end{array}$ & $2013[36]$ \\
\hline $\mathrm{HAp} / \mathrm{Pt}^{5}$ & $\begin{array}{c}\text { CV } \\
\text { SWASV }\end{array}$ & $\mathrm{Pb}$ & $4.14-2277$ & $\begin{array}{l}\text { River water } \\
\text { samples }\end{array}$ & 4.2 & 2013 [37] \\
\hline FAAS ${ }^{6}$ & FAAS & $\begin{array}{l}\mathrm{Cu} \\
\mathrm{Zn} \\
\mathrm{Pb}\end{array}$ & & & $\begin{array}{c}0.72 \\
0.55 \\
0.512\end{array}$ & 2015 [38] \\
\hline $\mathrm{HAp} / \mathrm{GCE}^{7}$ & $\begin{array}{c}\text { CV } \\
\text { SWASV }\end{array}$ & $\begin{array}{l}\mathrm{Cu} \\
\mathrm{Pb} \\
\mathrm{Cd}\end{array}$ & $\begin{array}{c}10-1000 \\
10-1000 \\
1-100\end{array}$ & $\begin{array}{l}\text { Real sugar and } \\
\text { honey samples }\end{array}$ & $\begin{array}{c}2.0 \\
10.0 \\
0.9\end{array}$ & $\begin{array}{c}2021 \\
\text { This work }\end{array}$ \\
\hline
\end{tabular}

${ }^{1}$ HAp-modified carbon ionic liquid electrode (HAp-CILE): ionic liquid N-octylpyridium hexafluorophosphate (OPPF(6)) with a ratio of $50 / 50(w / w=$ mixing the graphite powder with HAp to give an appropriate ratio of $\mathrm{HAp} / \mathrm{CP})$ and heating for 2 min at $>65{ }^{\circ} \mathrm{C} .{ }^{2} \mathrm{Mixture}$ of lead ionophore (IV) (4-tert-butylcalix[4] arene-tet-rakis(N,N-dimethylthioacetamide)) with nanosized hydroxyapatite (nHAp) prepared by one-step sonication for $20 \mathrm{~min}$ (from $\mathrm{Ca}\left(\mathrm{NO}_{3}\right)_{2}$ and $\left(\mathrm{NH}_{4}\right)_{2} \mathrm{HPO}_{4}$; the molar ratio of $\mathrm{Ca}$ and $\mathrm{P}$ was equal to 1.67 ) and $\mathrm{Nafion}$ dropwise on the GCE. ${ }^{3}$ One-step sonication: $\mathrm{CNTs}$ dispersed in solution with the aid of ultrasonication for $20 \mathrm{~min}$ with $\mathrm{Ca}\left(\mathrm{NO}_{3}\right)_{2}$ and $\left(\mathrm{NH}_{4}\right)_{2} \mathrm{HPO}_{4}$; the molar ratio of $\mathrm{Ca}$ and $\mathrm{P}$ was equal to $1.67 ; 10 \mathrm{~mL}$ of $1 \mathrm{mg} / \mathrm{mL}$ carbon nanotube-HAp ethanol solution was added on the surface of the GCE and dried under an IR lamp. ${ }^{4}$ Bismuth (in situ)-modified HAp carbon-modified electrode by adding different content ratios of HAp and graphite to the formation. ${ }^{5}$ Electrodeposition of HAp on the surface of a bare platinum electrode. ${ }^{6}$ After preconcentration with hydroxyapatite nanorods originating from an eggshell. ${ }^{7}$ Electrodeposition of HAp on the surface of a glassy carbon electrode via the electrochemical deposition of and chemical conversation to HAp.

\section{Materials and Methods}

Chemicals, Solutions, and Apparatus All used reagents were of analytical reagent grade. All of the solutions were prepared with double-distilled water. The Sigradur ${ }^{\circledR}$ glassy carbon was supplied from Hochtemperatur-Werkstoffe $\mathrm{GmbH}$, Thierhaupten, Germany.

Preparation of the GC Electrode Before use, the glassy carbon (GC) electrodes (5 mm in diameter), which served as substrate electrodes in all experiments, were mechanically polished with emery paper (2000 grit), followed by polishing with alumina powder down to $0.05 \mu \mathrm{m}$. After polishing, the electrodes were treated ultrasonically in redistilled water, rinsed with ethanol, and finally rinsed with redistilled water.

In order to achieve a reproducible and active electrode surface, the electrodes were activated in $0.5 \mathrm{~mol} \mathrm{dm}^{-3} \mathrm{HNO}_{3}$, as noted in our previous study [32].

Preparation of HAp/GC Electrode The Ca/P-phase electrodeposition solution was prepared by mixing $50 \mathrm{~cm}^{3}$ of $0.05 \mathrm{~mol} \mathrm{dm}{ }^{-3} \mathrm{Ca}\left(\mathrm{NO}_{3}\right)_{2} \cdot 4 \mathrm{H}_{2} \mathrm{O}$ and $50 \mathrm{~cm}^{3}$ of $0.04 \mathrm{~mol} \mathrm{dm}^{-3}$ $\left(\mathrm{NH}_{4}\right)_{2} \mathrm{HPO}_{4}$. The $\mathrm{pH}$ of the solution was adjusted to 5.0 by adding $0.5 \mathrm{~mol} \mathrm{dm}-3 \mathrm{HNO}_{3}$. Electrodeposition was performed at a potential of $-850 \mathrm{mV}$ for $60 \mathrm{~min}$ at room temperature. 
The electrolyte was stirred with a magnetic stirrer at a constant speed. In that way, the concentration of $\mathrm{Ca}^{2+}$ and $\mathrm{HPO}_{4}{ }^{2-}$ ions was constant during electrodeposition.

Alkaline treatment was performed in a bath with $1.0 \mathrm{~mol} \mathrm{dm}{ }^{-3} \mathrm{NaOH}$ at $80{ }^{\circ} \mathrm{C}$ for $60 \mathrm{~min}$ after electrodeposition. Between each step, the electrode was cleansed with redistilled water.

As a result of the preparation procedure, a HAp/GC electrode was obtained.

Instruments All experiments were carried out at $25^{\circ} \mathrm{C}$.

The surface morphology was studied using a FEG-SEM Thermo Scientific ${ }^{\mathrm{TM}}$ Quattro ESEM scanning electron microscope (SEM). Obtained images were quantified using ImageJ software (Rasband, U.S. NIH, Bethesda, MD, USA). Preliminary examination of the sample surface was conducted using a metallographic microscope (MMT 800BT, Mikrolab, Warsaw, Poland), and the surface topography of the samples was evaluated using an atomic force microscope (AFM, Dimension Icon, Bruker, Santa Barbara, CA, USA) in tapping mode using a standard silicon probe model TESPA-V2 (Bruker, Santa Barbara, CA, USA). Achieved images were quantified with ImageJ software (Rasband, U.S. NIH, Bethesda, MD, USA). Electrochemical impedance measurements were made using Solartron SI 1287 and SI $1255 \mathrm{HF}$ frequency response analyzer (FRA) instruments. The Solartron instruments were controlled using Zplot and CorrWare computer software, while ZView and CorrView software packages were used as tools for data analysis. For electrochemical voltammetric measurements, a three-electrode cell was used with $\mathrm{Ag} / \mathrm{AgCl} / 3 \mathrm{M} \mathrm{KCl}$ as the reference electrode, a platinum electrode as the counter electrode, and GC or HAp/GC as the working electrode with a potentiostat (AutoLab PGSTAT 302N) connected to a PC and driven by GPES4.9 software (Eco Chemie).

Preparations of Sugar and Honey Samples A representative sample (sample of sugar purchased from a local store and two samples of honey purchased from a local beekeeper from two localities: mountainous and coastal) of up to $2.0 \mathrm{~g}$ was digested in concentrated nitric acid, and the mixture was left in the digester for $24 \mathrm{~h}$. The mixture was transferred to porcelain pots, which were annealed at $160{ }^{\circ} \mathrm{C}$ for $30 \mathrm{~min}$. After cooling, $8 \mathrm{~mL}$ of $\mathrm{H}_{2} \mathrm{O}_{2}$ and $2 \mathrm{~mL}$ of $\mathrm{HNO}_{3}$ were added. The resulting solution was completely clarified. A $10 \mathrm{~mL}$ volume of aliquots of the prepared samples $\left(\mathrm{pH}=4\right.$, adjusted with $\left.\mathrm{HNO}_{3}\right)$ was transferred to a $100 \mathrm{~mL}$ flask and filled with $0.2 \mathrm{~mol} \mathrm{dm}{ }^{-3}$ solution of $\mathrm{KNO}_{3}$.

\section{Results}

3.1. Electrodeposition of Ca/P Phases on the GC Electrode and Surface Morphology of the HAp Coating on the GC Electrode

\subsubsection{Deposition}

For the surface modification of the HAp coating on the GC electrode, a two-part method was performed [19]. The first part comprised the electrochemical and chemical reactions. Electrodeposition was performed at a potential of $-850 \mathrm{mV}$ at room temperature for $60 \mathrm{~min}$. Electrochemical reactions involve the reduction of hydrogen (electrochemical reaction) and the spontaneous deposition of $\mathrm{Ca} / \mathrm{P}$ phases (chemical reaction) when the $\mathrm{Ca}^{2+}$ ion reacts with $\mathrm{HPO}_{4}{ }^{2-}$ and $\mathrm{PO}_{4}{ }^{3-}$ and forms $\mathrm{CaHPO}_{4} \times 2 \mathrm{H}_{2} \mathrm{O}$ (brushite, calcium hydrogen phosphate dihydrate) and $\mathrm{Ca}_{3}\left(\mathrm{PO}_{4}\right)_{2}$ (calcium phosphate, $\beta$-TCP). Brushite and $\beta$-TCP are precursors to the formation of stable-phase HAp and $\mathrm{Ca}_{10}\left(\mathrm{PO}_{4}\right)_{6}(\mathrm{OH})_{2}$. The second part is chemical conversation via reactions that convert deposited $\mathrm{Ca} / \mathrm{P}$ phases into hydroxyapatite (HAp) through alkaline treatment. Scheme 1 presents the process of deposition under the given experimental conditions.

\subsubsection{Atomic Force Microscopy (AFM)}

An example optical microscopy image of the surface of each sample and AFM images of the scanning areas of $10 \times 10 \mu \mathrm{m}$ are shown below in Figure 1 . The optical microscopy images indicate that the surfaces of the tested samples are heterogeneous and not totally covered. From the microscopic images, it is possible to conclude that part of the GC surface is unmodified carbon, an uncovered surface, or microcracks with carbon in a small gap, 
probably due to a nonformed nucleus during the electrodeposition step. The formed film was evaluated with ImageJ software. A cross-sectional view is generated from the optical image and presented as the ZY or ZX planes. The obtained AFM images characterize the surface locally, and scans at different locations show noticeable differences in surface roughness. According to the AFM images, the mean image data plane (Rq) calculated on $100 \mu^{2}$ regions for two different positions on the surface varies from 107.3 down to $35.5 \mathrm{~nm}$ for different film thicknesses (900.8 and $280.8 \mathrm{~nm}$; Figure 1C,D).

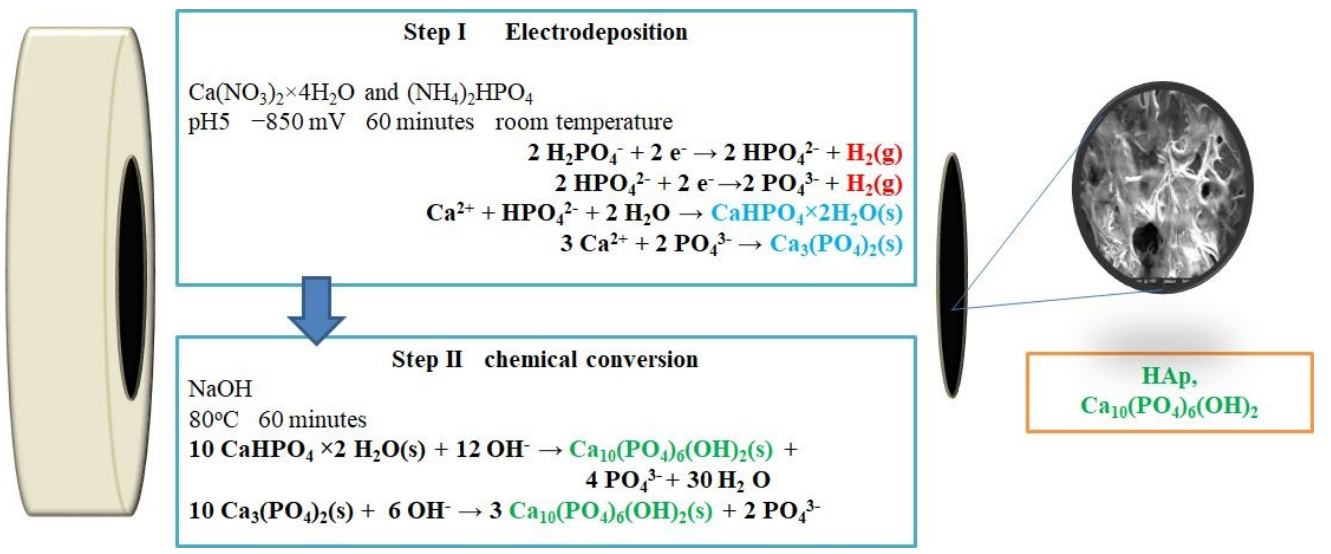

Scheme 1. Process of deposition under the given experimental conditions.
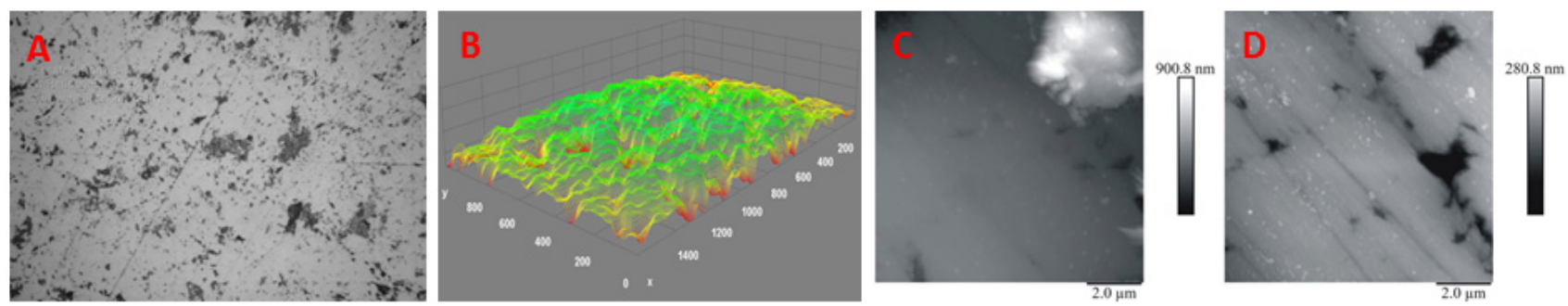

Figure 1. Optical image of the HAp film at 500 $\times$ magnification: (A) cross-sectional view generated from the optical image (B) and film thickness measurements using AFM (C,D).

\subsubsection{Scanning Electron Microscopy (SEM)}

Figure 2 shows the surface morphologies of HAp on the GC surface with different magnifications: $35 \times$ (Figure 2A), $1000 \times$ (Figure 2B), and 8000 $\times$ (Figure 2C). For the HAp coating with a magnification of $8000 \times$ (Figure $2 \mathrm{C}$ ), it can be seen that a porous structure formed on the GC surface with HAp, with a macropore diameter between 0.5 and $3 \mu \mathrm{m}$. The macropores led to the development of a large specific surface area and an "open structure", which is of great importance for good electroanalytical performance.

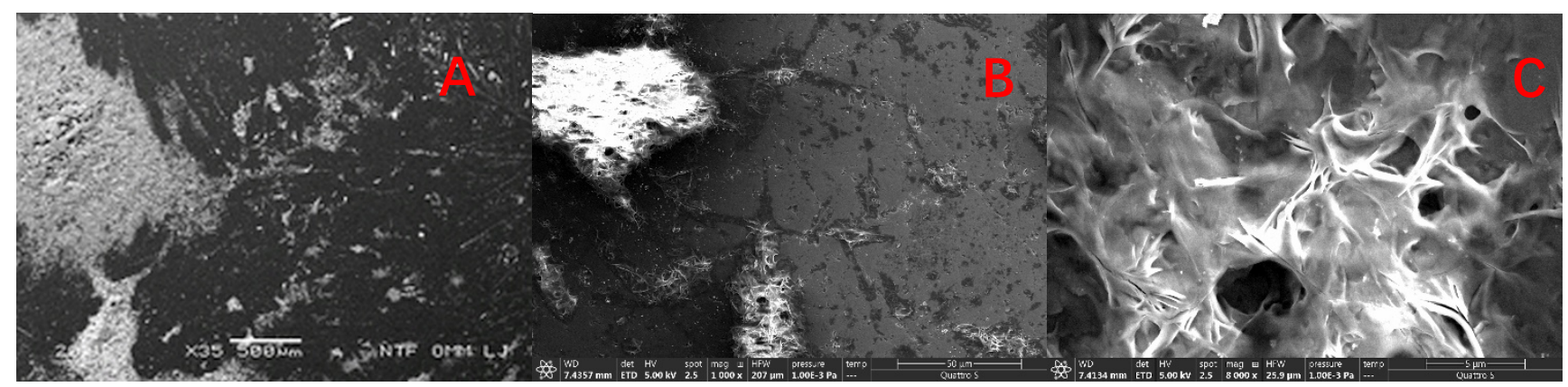

Figure 2. SEM results with three different magnifications of the electrode surface: (A) $35 \times$ (B) $1000 \times($ C) $8000 \times$; film was electrodeposited on a polished glassy carbon electrode $\left(E_{\mathrm{dep}}=-0.850 \mathrm{~V} ; t_{\mathrm{dep}}=60 \mathrm{~min}\right)$. 
In our previous study [19], we reported that this method of modifying results in a relatively uniform topology and almost completely covered surfaces with an average content of elements derived by energy-dispersive spectroscopy (EDS) analysis corresponds to the formation of a P-deficient topology (Ca-fortified apatite), with a $\mathrm{Ca} / \mathrm{P}$ ratio of 2.12, which was not found to be a biologically relevant $\mathrm{Ca} / \mathrm{P}$ form. In the natural bone, the $\mathrm{Ca} / \mathrm{P}$ ratio is close to 1.67 with an oxygen atomic content of $\sim 62 \%$ [24].

\subsubsection{Fourier-Transform Infrared Spectroscopy (FTIR)}

FTIR spectroscopy is a useful method to verify the presence of functional groups in synthesized compounds or materials in a wide wavenumber region. Figure 3 shows the FTIR spectra of the bare (blue line) and HAp-modified (red line) GC electrodes prepared as described in the Materials and Methods section (Section 2).

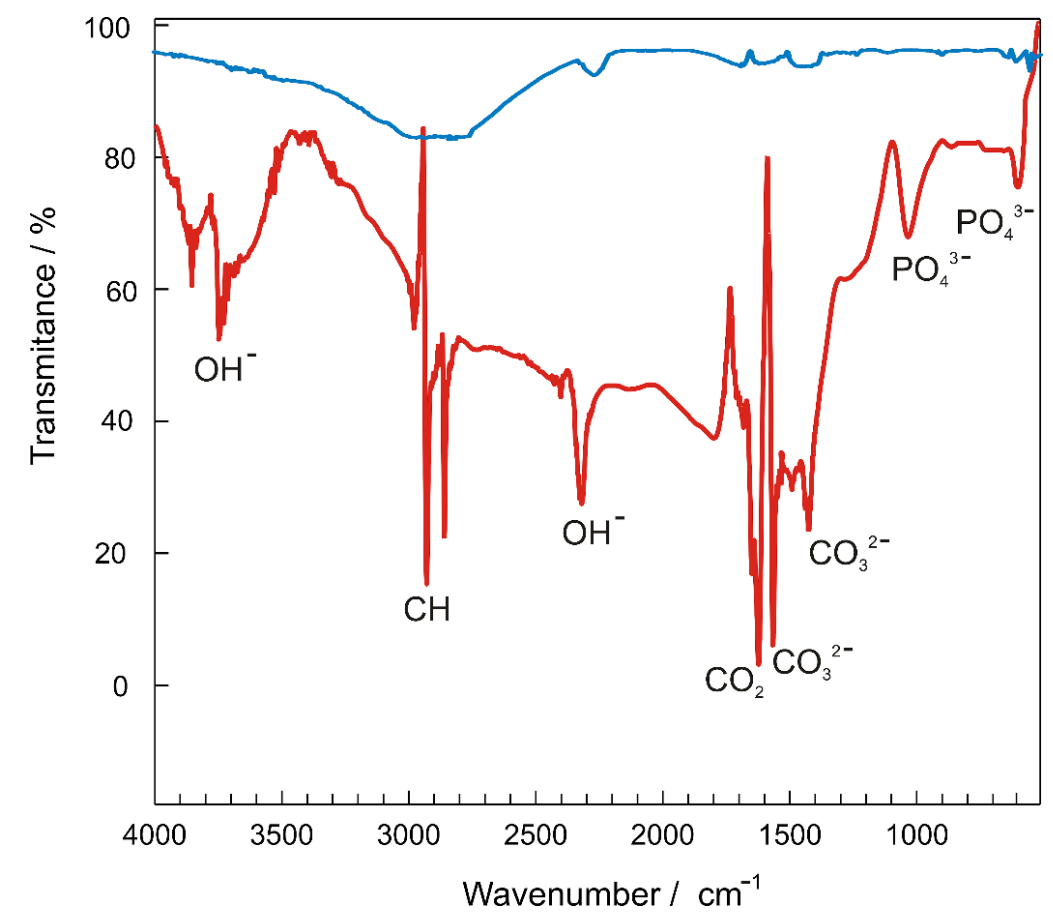

Figure 3. FTIR spectra of the bare (blue line) and HAp-modified GC electrodes (red line).

The observed peaks on the bare GC electrode are identified as follows. One strong shoulder peak observed between 2830 and $3050 \mathrm{~cm}^{-1}$ can be connected to the absorption of C-H stretching that corresponds to the frequency of asymmetric $\left(2919 \mathrm{~cm}^{-1}\right)$ and symmetric $\left(2848 \mathrm{~cm}^{-1}\right)$ stretching of the $\mathrm{C}-\mathrm{H}$ bond from the methyl moiety $\left(-\mathrm{CH}_{2}\right)$, which originated from organic impurities. The peak at $2330 \mathrm{~cm}^{-1}$ is due to $\mathrm{O}-\mathrm{H}$ stretching, and the peaks at 1472 and $1400 \mathrm{~cm}^{-1}$ can be associated with the vibration of the traces of organic substances on the surface, or the vibration of a $\mathrm{CO}_{3}{ }^{2-}$ group, formed as a consequence of anodic or cathodic pretreatment in nitric acid. After modification, FTIR of the HAp/GC electrode shows some peaks characteristic of HAp $[19,35]$.

The surface of HAp on the GC electrode showed some characteristic peaks [19,39]:

(1). The strong characteristic band in the $3400-3900 \mathrm{~cm}^{-1}$ frequency range and at $2310 \mathrm{~cm}^{-1}$ is assigned to $\mathrm{O}-\mathrm{H}$ stretching.

(2). The peaks at 2848 and $2919 \mathrm{~cm}^{-1}$ of $\mathrm{C}-\mathrm{H}$ stretching from the methyl moiety $\left(-\mathrm{CH}_{2}\right)$, which originated from organic impurities, suggest a noncovered GC surface.

(3). The peak at $1623 \mathrm{~cm}^{-1}$ was due to adsorbed atmospheric $\mathrm{CO}_{2}$, and the peaks at 1540 and $1380 \mathrm{~cm}^{-1}$ can be attributed to the vibration of traces of organic substances on the surface or the vibration of a $\mathrm{CO}_{3}{ }^{2-}$ group. 
(4). The most prominent peaks at $1015 \mathrm{~cm}^{-1}$ are due to the asymmetrical $\mathrm{P}-\mathrm{O}$ stretching mode of HAp in phosphate.

(5). The slight shoulders at 961 and $560 \mathrm{~cm}^{-1}$ and the peak at $604 \mathrm{~cm}^{-1}$ are ascribed to the $\mathrm{P}-\mathrm{O}$ bending mode from phosphate.

The FTIR results confirm the presence of a HAp film on the GC surface.

\subsubsection{Electrochemical Impedance Spectroscopy (EIS) Studies of HAp/GC}

Interference properties, as well as the surfaces of modified and nonmodified electrodes and the absorption of an optimized HAp film on the GC electrode surface, were investigated using electrochemical impedance spectroscopy (EIS) in $0.2 \mathrm{M} \mathrm{KNO}_{3}(\mathrm{pH}=4)$. Figure 4 shows the impedance data as Nyquist plots, obtained for bare GC and modified HAp/GC via the electrodeposition process, as described in the Materials and Methods section (Section 2). Impedance data were fitted by a suitable electrical equivalent circuit (EEC) model, employing the complex nonlinear least-squares fit analysis [40] offered by Solartron $\mathrm{ZView}^{\circledR}$ software. The fitting quality was evaluated by the chi-squared and relative error values, which were of the order of $10^{-3}-10^{-4}$ and below $5 \%$, respectively, indicating that the agreement between the proposed EEC model and the experimental data was good. The total impedance, $Z$ of the investigated electrochemical system is the sum of the ohmic resistance and the impedance of the electrochemical interface $\left(Z_{\mathrm{el}}+Z_{\mathrm{HF}}+Z_{\mathrm{LF}}\right)$ and is described by the transfer function in Equation (1).

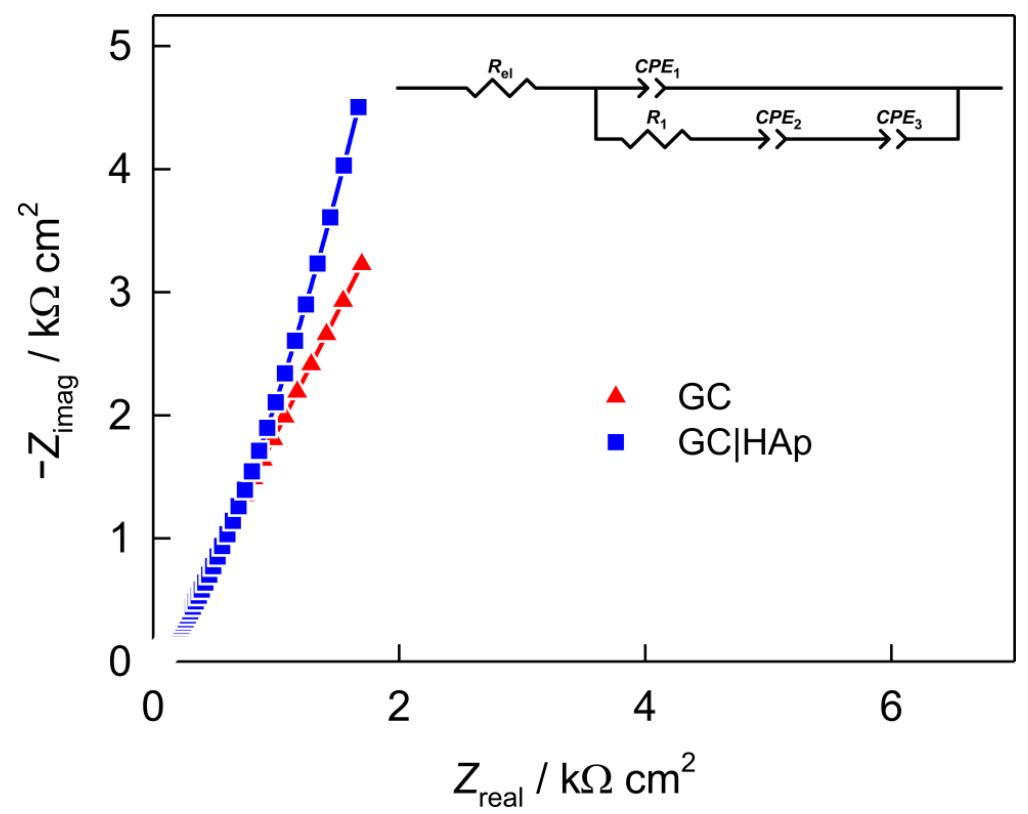

Figure 4. Nyquist plot of the unmodified and modified GC electrodes recorded at $E_{\mathrm{OCP}}$ in $0.2 \mathrm{M} \mathrm{KNO}_{3}$ $(\mathrm{pH}=4)$ solution. Inset: The EEC used to fit the EIS data $\left(E_{\mathrm{OCP}}\right.$ for bare the GC electrode $=0.0505 \mathrm{~V}$ and for the HAp/GC electrode $=0.0727 \mathrm{~V}$ ).

The Nyquist plots suggest the presence of the diffusion process. EIS data were modeled by the electrical equivalent circuit (EEC) with three time constants, as shown in the inset in Figure 4. In the EEC, constant phase element $C P E_{1}$ is attributed to the double layer capacitance, $R_{1}$ to the charge transfer resistance, $C P E_{2}$ to the capacitance of the species traveling through the film, and $C P E_{3}$ to the diffusion processes [41]. The numerical values of the EEC elements were obtained by the fitting procedure. The presented recorded plots reveal the diffusion-controlled processes that took place at the HAp/GC interface. The electrolyte resistance was $6.1 \Omega \mathrm{cm}^{2}$. The numerical values of the EEC elements obtained by the fitting procedure indicate an increase in charge transfer resistance in the case of the 
modified electrode, suggesting that the adsorbed layer inhibits charge transfer (from 47 to $113 \Omega \mathrm{cm}^{2}$ ). The EIS results are in agreement with the FTIR results.

$$
Z_{\text {TOTAL }}(j \omega)=R_{e l}+\left\{Q_{1}(j \omega)^{n 1}+\left\{R_{1}+\left[Q_{2}(j \omega)^{n 2}+Q_{3}(j \omega)^{n 3}\right]^{-1}\right\}^{-1}\right\}^{-1}
$$

\subsubsection{Electrochemical Methods}

As the main inorganic constituents of biological hard tissues such as bones or teeth, HAp has a hexagonal structure, which can be self-polymerized during alkaline treatment. The sorption mechanisms of the heavy metals on HAp are diverse and mainly include ion exchange, dissolution/precipitation, and the spontaneous formation of surface complexes due to its unique channel structure [38]. The possible exchange of calcium ions with the target metal can be present as follows (Scheme 2).

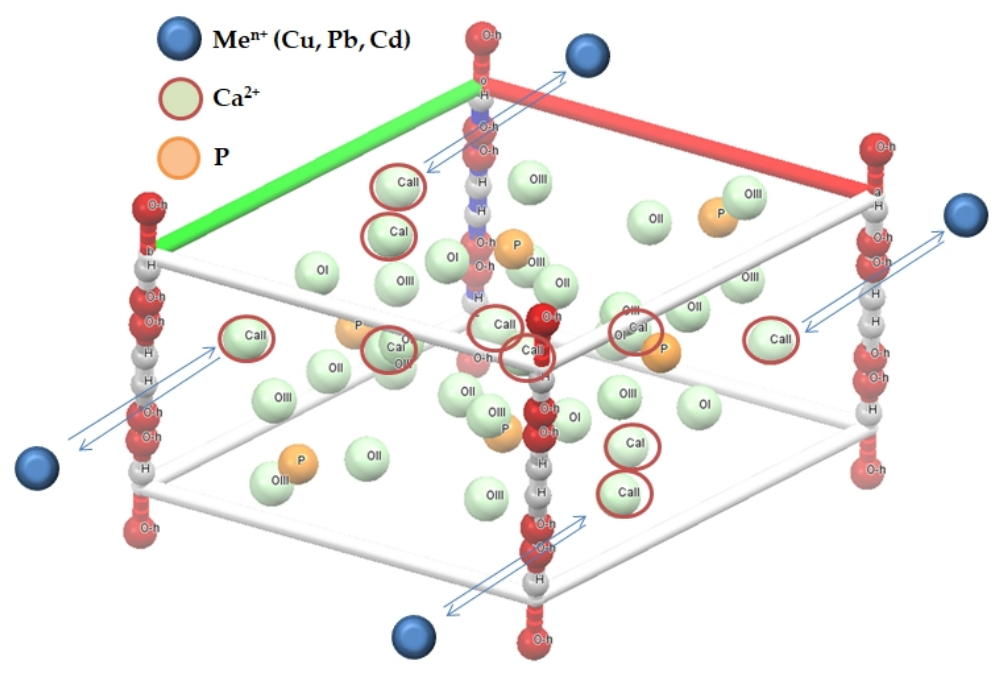

Scheme 2. Spontaneous formation of surface complexes due to its unique open-channel structure.

Prior to the investigation of the possibilities for the application of a prepared HAp/GC electrode for an electroanalytical purpose, the electrochemical properties of the prepared HAp/GC electrode were examined. Cyclic voltammograms obtained at the HAp/GC electrode are presented in Figure 5.

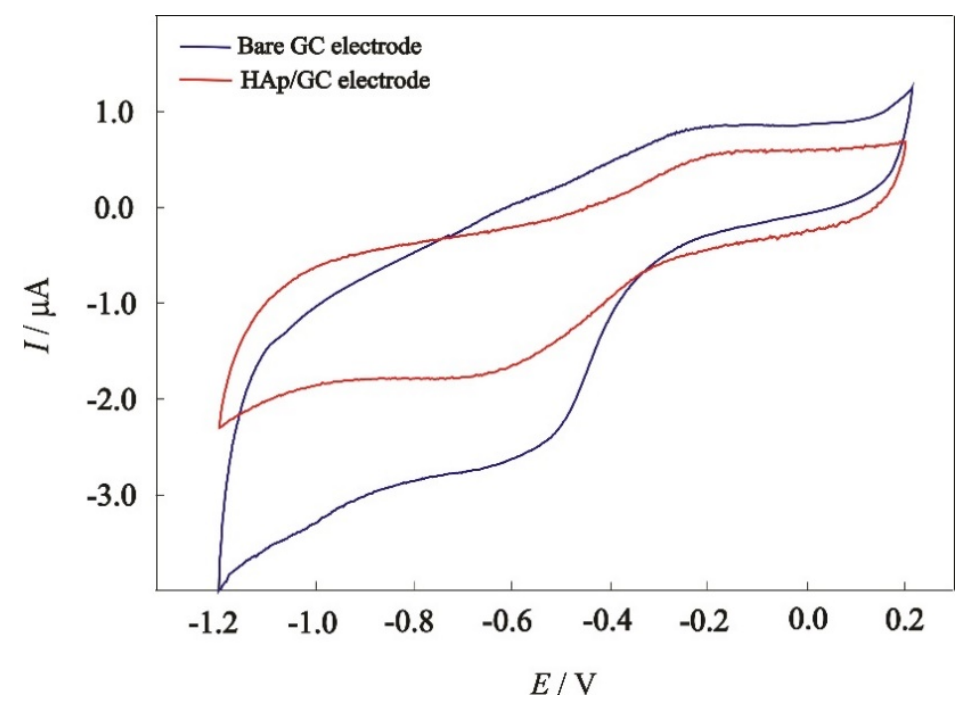

Figure 5. Cyclic voltammograms obtained on a bare GC electrode and a HAp/GC electrode in $0.2 \mathrm{M}$ $\mathrm{KNO}_{3}(\mathrm{pH}=4)$ with a scan rate of $25 \mathrm{mV} / \mathrm{s}$, going from $0.0 \mathrm{~V}$ to the cathodic direction. 
These measurements were carried out without oxygen removed from the solution. The overpotential of hydrogen reduction on the HAp/GC electrode was very low. The presence of $\mathrm{O}_{2}$ affects the background. The obtained voltammograms revealed an intensive reduction signal at $-0.5 \mathrm{~V}$ and an oxidation signal at $-0.2 \mathrm{~V}$, corresponding to the full reduction of oxygen. The oxygen reduction reaction ideally takes the four-electron pathway $\left(\mathrm{O}_{2}+4 \mathrm{H}^{+}\right.$ $+4 \mathrm{e}^{-} \leftrightarrow 2 \mathrm{H}_{2} \mathrm{O}$ ). The potential of this reaction is similar to that reported for the oxygen reduction reaction at a bare glassy carbon electrode [42]. Afterward, the modification of the electrode reduction/oxidation peak that corresponds to oxygen is significantly reduced, which suggests a low sensitivity of the electrode to the oxygen present in the solution. The overpotential of hydrogen reduction at the HAp/GC electrode was very low. The presence of dissolved $\mathrm{O}_{2}$ could also reduce the potential window of the bare GC electrode, but the modified electrode could be used in a wider potential window with regard to the bare GC electrode.

\section{Discussion}

\subsection{Analytical Applicability}

A methodology for the determination of $\mathrm{Cu}, \mathrm{Pb}$, and $\mathrm{Cd}$ by square wave anodic stripping voltammetry (SWASV) at proposed electrodes in honey and sugar samples was proposed.

Such modified electrodes were subsequently used for the determination of heavy metal cations individually with optimized parameters. The SWCSV procedure was established by monitoring the influence of the applied potential increment $\left(\Delta E_{\mathrm{S}}\right)$, frequency $(f)$, pulse height $\left(\Delta E_{\mathrm{p}}\right)$, accumulation potential $\left(E_{\mathrm{acc}}\right)$, and accumulation time $\left(t_{\mathrm{acc}}\right)$ on peak currents $\left(I_{\mathrm{p}}\right)$, and the obtained results are shown in Table 2. The SWCS voltammograms were obtained by the standard addition method (Figure 6). The calibration plots of the HAp/GC electrode towards copper, lead, and cadmium were derived from the obtained voltammograms, and the results are shown as insets of Figure 6.

Table 2. Optimization parameters for the individual determination of copper, lead, and cadmium.

\begin{tabular}{|c|c|c|c|}
\hline & $\mathrm{Cu}^{2+}$ & $\mathrm{Pb}^{2+}$ & $\mathrm{Cd}^{2+}$ \\
\hline Supporting electrolyte & $0.2 \mathrm{M} \mathrm{KNO}_{3}$ & $0.2 \mathrm{M} \mathrm{KNO}_{3}$ & $0.2 \mathrm{M} \mathrm{KNO}_{3}$ \\
\hline $\mathrm{pH}$ & 4 & 4 & 4 \\
\hline Accumulation potential & $-500 \mathrm{mV}$ & $-1000 \mathrm{mV}$ & $-1200 \mathrm{mV}$ \\
\hline Accumulation time & $300 \mathrm{~s}$ & $240 \mathrm{~s}$ & $120 \mathrm{~s}$ \\
\hline Frequency & $50 \mathrm{~Hz}$ & $50 \mathrm{~Hz}$ & $50 \mathrm{~Hz}$ \\
\hline Potential increment & $5 \mathrm{mV}$ & $5 \mathrm{mV}$ & $5 \mathrm{mV}$ \\
\hline Pulse height & $50 \mathrm{mV}$ & $50 \mathrm{mV}$ & $20 \mathrm{mV}$ \\
\hline Stripping potential & $\sim 100 \mathrm{mV}$ & $\sim 400 \mathrm{mV}$ & $\sim 700 \mathrm{mV}$ \\
\hline Concentration region with linear responses & $\begin{array}{c}10 \mu \mathrm{g} \mathrm{L}^{-1}-100 \mu \mathrm{g} \\
100-1000 \mu \mathrm{g} \mathrm{L}-1\end{array}$ & $\begin{array}{c}10 \mu \mathrm{g} \mathrm{L}^{-1}-100 \mu \mathrm{g} \\
100-1000 \mu \mathrm{g} \mathrm{L} \mathrm{L}^{-1}\end{array}$ & $\begin{array}{c}1.0 \mu \mathrm{g} \mathrm{L}^{-1}-10 \mu \mathrm{g} \\
10-100 \mu \mathrm{g} \mathrm{L}-1\end{array}$ \\
\hline Correlation coefficient $\mathrm{R}^{2}$ & 0.998 & 0.989 & 0.986 \\
\hline Correlation coefticient, $\mathrm{R}^{2}$ & 0.994 & 0.993 & 0.994 \\
\hline Sensitivity & $\begin{array}{l}0.03 \mu \mathrm{A} \mu \mathrm{g} \mathrm{L}^{-1} \\
0.04 \mu \mathrm{A} \mu \mathrm{g} \mathrm{L}^{-1}\end{array}$ & $\begin{array}{l}0.09 \mu \mathrm{A} \mu \mathrm{g} \mathrm{L}^{-1} \\
0.19 \mu \mathrm{A} \mu \mathrm{g} \mathrm{L}^{-1}\end{array}$ & $\begin{array}{l}0.11 \mu \mathrm{A} \mu \mathrm{g} \mathrm{L}^{-1} \\
0.03 \mu \mathrm{A} \mu \mathrm{g} \mathrm{L}^{-1}\end{array}$ \\
\hline
\end{tabular}

During accumulation, selected potential from the adsorbed metal-apatite-targeting metal ion is reduced and then "stripped" from the surface. The change in slope, with linearity preserved, can be attributed to the increased amount of target metal accumulated at the electrode surface, resulting in saturation of the electrode surface. However, this will not take effect on the analytical performances of the modified electrode, as these ranges are well defined and reproducible. For higher metal concentrations, some authors suggest a shorter accumulation time. 

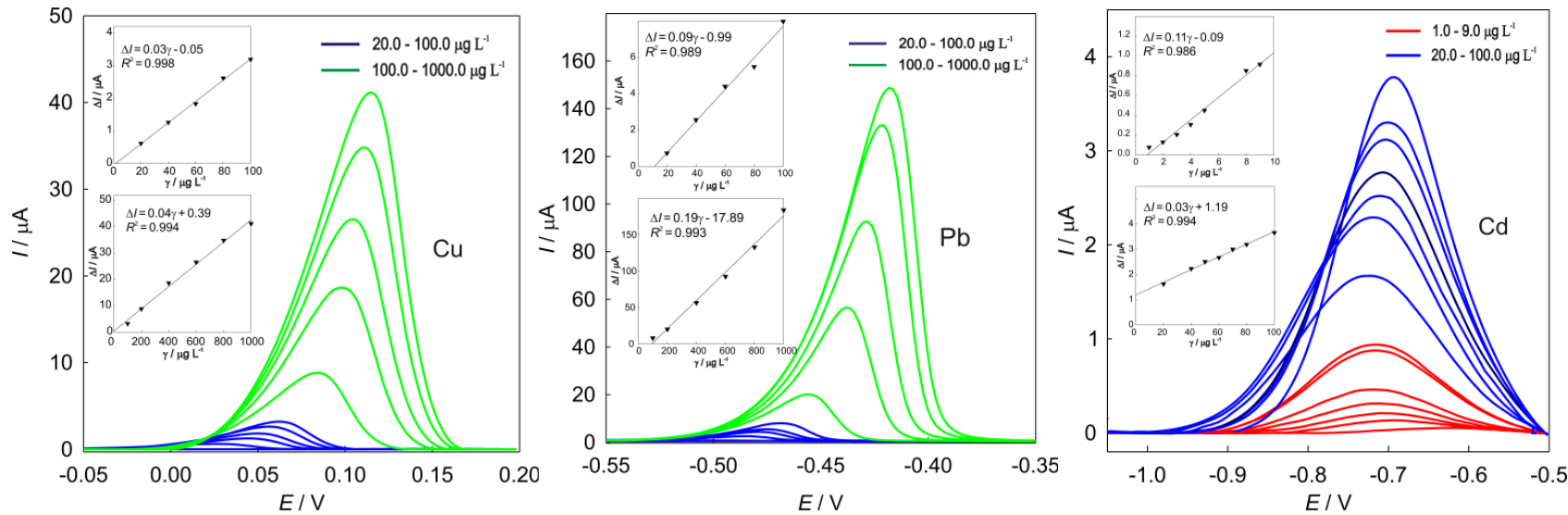

Figure 6. SWCSVs (baseline corrected), recorded at the HAp/GC electrode in $0.2 \mathrm{M} \mathrm{KNO}_{3}(\mathrm{pH}=4)$, with corresponding calibration plots derived by subtracting the background current from the corresponding voltammograms of copper, lead, and cadmium.

\subsection{Analytical Application of HAp/GC Electrode in Real Samples}

In order to evaluate the analytical applicability of the prepared modified electrode, the proposed method was applied for the detection of $\mathrm{Cu}, \mathrm{Pb}$, and $\mathrm{Cd}$ in the real sample (honey and sugar) purchased from a local store, and the results are presented in Table 3 , with examples of the SWCSVs of the prepared real sample showed presented in Figure 7. The concentrations of metals were obtained using the standard addition method. Besides being able to overcome the sample's matrix interference, this method can also be used to determine low concentrations of analytes with excellent linearity. The results of the proposed method were compared with the results obtained by the standard analytical method (not shown). The method showed good agreement for copper and cadmium. Large deviations appear in the case of lead, suggestive of potential metal interferences in the determination of lead. For lead determination in sugar, another method must be performed.

Table 3. Obtained concentrations of $\mathrm{Cu}, \mathrm{Pb}$, and $\mathrm{Cd}$ in sweeteners (honey and sugar).

\begin{tabular}{|c|c|c|c|c|c|c|c|c|c|}
\hline \multirow[t]{2}{*}{ Real Sample } & \multicolumn{3}{|c|}{ Honey 1} & \multicolumn{3}{|c|}{ Honey 2} & \multicolumn{3}{|c|}{ Sugar } \\
\hline & $\mathrm{Cu}$ & $\mathbf{P b}$ & $\mathrm{Cd}$ & $\mathrm{Cu}$ & $\mathbf{P b}$ & $\mathrm{Cd}$ & $\mathrm{Cu}$ & $\mathrm{Pb}$ & $\mathrm{Cd}$ \\
\hline$\mu \mathrm{g} \mathrm{kg}^{-1}$ & $1775 \pm 47$ & $587.5 \pm 22.1$ & $64.3 \pm 1.7$ & $373.0 \pm 12.0$ & $4410 \pm 66$ & $287.4 \pm 12.6$ & $693.7 \pm 23.5$ & $823.7 \pm 13.5$ & $360.0 \pm 2.7$ \\
\hline $\begin{array}{l}\text { Maximum } \\
\text { Qty Allowed }\end{array}$ & 2000 & 300 & 300 & 2000 & 300 & 300 & 1000 & 500 & 500 \\
\hline
\end{tabular}
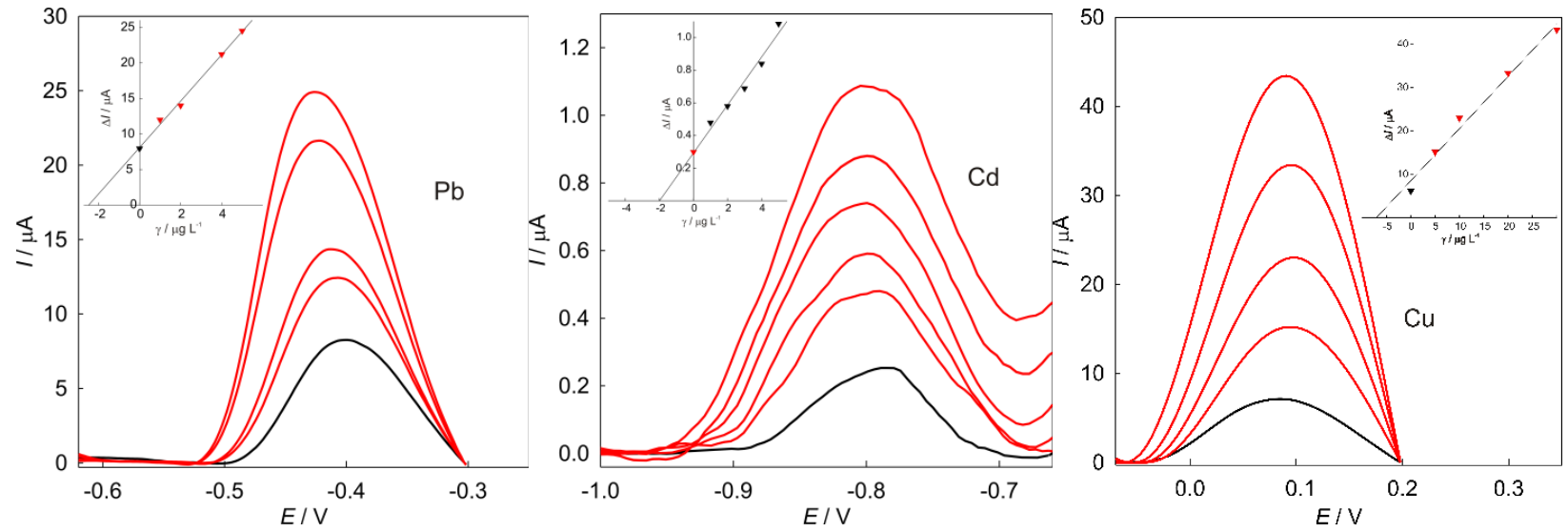

Figure 7. Examples of the SWCSVs of the prepared real sample (baseline corrected), recorded at the HAp/GC electrode in $0.2 \mathrm{M} \mathrm{KNO}_{3}$ solution $(\mathrm{pH}=4)$ together with the background response: lead in Honey 1, cadmium in Honey 2, and copper in sugar. The insets show the corresponding calibration plots. 


\section{Conclusions}

In the current work, a chronoamperometric procedure for the preparation of the openchannel structure of HAp was presented, and a possible coordination structure (HAp/GC electrode) with heavy metals was introduced.

High porosity, a film with an open structure, good mechanical characteristics, and reproducibility in terms of the deposited film are achieved with the combined electrochemical and chemical steps for deposition and conversion. The FTIR study confirmed the existence of functional groups, characteristics of the HAp film, and the possibility of the adsorption/accumulation of heavy metals on the electrode surface. The developed method for controlled HAp deposition results in the HAp morphology of a nanosized material with a uniform pore size distribution, which was confirmed with numerous methods for surface analysis, suitable for selective adsorption.

Under the optimized conditions, a linear response between 10 and $1000 \mu \mathrm{g} / \mathrm{L}$ for $\mathrm{Cu}$ and $\mathrm{Pb}$ and 1 and $100 \mu \mathrm{g} / \mathrm{L}$ for $\mathrm{Cd}$ with an estimated detection limit of 2.0, 10.0 and $0.9 \mu \mathrm{g} / \mathrm{L}$, respectively, were obtained. The development method was applied in complex matrices such as honey and sugar samples. In conclusion, commercial honey and sugar are safe as the amount of daily allowance without any harmful contamination of heavy metals.

Surface modification of the GC electrode with the HAp film significantly increased its sensitivity toward metal determination. However, the future prospects of this preparation and procedure can provide easy-to-handle, rapid, low-cost, highly sensitive, stable, and, with appropriate modification, even highly selective biosensors.

Author Contributions: Conceptualization, I.Š.R.; and N.V.; methodology, N.V.; validation, I.Š.R.; and N.V., formal analysis, M.B. (Marijo Buzuk); investigation, M.B. (Maša Buljac); resources, N.V.; data curation, N.V.; writing—original draft preparation, N.V.; writing—review and editing, I.Š.R.; visualization, I.Š.R.; supervision, M.B. (Marijo Buzuk). All authors have read and agreed to the published version of the manuscript.

Funding: This research received no external funding.

Data Availability Statement: Not applicable.

Acknowledgments: The authors gratefully acknowledge contribution of Samo Smolej from for the Department of Materials and Metallurgy, University of Ljubljana, Faculty of Natural Sciences and Engineering, Slovenia and Andrzej Leniart Department of Inorganic and Analytical Chemistry University of Lodz, Faculty of Chemistry, Poland for their contribution to obtain SEM-EDS and AFM images.

Conflicts of Interest: The authors declare no conflict of interest.

\section{References}

1. Di, N.; Zhang, K.; Hladun, K.R.; Rust, M.; Chen, Y.-F.; Zhu, Z.-Y.; Liu, T.X.; Trumble, J.T. Joint effects of cadmium and copper on Apis mellifera foragers and larvae. Comp. Biochem. Physiol. Part C Toxicol. Pharmacol. 2020, 237, 108839. [CrossRef]

2. Sousa, M.; Benson, B.; Welty, C.; Price, D.; Thirkill, R.; Erickson, W.; Cummings, M.; Dunnivant, F. Atmospheric deposition of coal-related pollutants in the Pacific Northwest of the United States from 1950 to 2016. Environ. Tox. Chem. 2019, 39, 335-342. [CrossRef]

3. Zhou, Q. Interactions between heavy metals and nitrogen fertilizers applied to soil-vegetable systems. Bull. Environ. Contam. Tox. 2003, 71, 338-344. [CrossRef]

4. Herawati, N.; Suzuki, S.; Hayashi, K.; Rivai, I.F.; Koyama, H. Cadmium, Copper, and Zinc Levels in Rice and Soil of Japan, Indonesia, and China by Soil Type. Bull. Environ. Contam. Toxicol. 2000, 64, 33-39. [CrossRef]

5. Herrero-Latorre, C.; Barciela-García, J.; García-Martín, S.; Peña-Crecente, R.M. The use of honeybees and honey as environmental bioindicators for metals and radionuclides: A review. Environ. Rev. 2017, 25, 463-480. [CrossRef]

6. Conti, M.E.; Botrè, F. Honeybees and Their Products as Potential Bioindicators of Heavy Metals Contamination. Environ. Monit. Assess 2001, 69, 267-282. [CrossRef]

7. Soares, S.; Amaral, J.S.; Oliveira, M.B.P.P.; Mafra, I. A Comprehensive Review on the Main Honey Authentication Issues: Production and Origin. Compr. Rev. Food Sci. Saf. 2017, 16, 1072-1100. [CrossRef]

8. Shah, A.; Sikandar, F.; Ullah, I.; Shah, A.; Ud-Din Khan, S.; Ali Rana, U.; McCoy, T. Spectrophotometric Determination of Trace Elements in various Honey Samples, Collected from different Environments. Food. Nutr. Res. 2014, 2, 532-538. [CrossRef] 
9. López-García, I.; Viñas, P.; Blanco, C.; Hernández-Córdoba, M. Fast determination of calcium, magnesium and zinc in honey using continuous flow flame atomic absorption spectrometry. Talanta 1999, 49, 597-602. [CrossRef]

10. Hassan, A.; Mahmoud, A.A.; Ghandour, A.A.M.M.; Mahran, H.A. Evaluation of lead, cadmium and copper concentrations in bee honey. Am. J. Appl. Sci. 2010, 7, 315-322. [CrossRef]

11. Chen, L.Z.; Rui, Y.K.; Zhao, J.; Ye, Z.H.; Xue, X.F.; Wang, P. Application of ICP-MS to detection of trace elements and heavy metals in different kinds of honey. Guang Pu Xue Yu Guang Pu Fen Xi/Spectrosc. Spect. Anal. 2008, 28, 1403-1405.

12. Ioannidou, M.D.; Zachariadis, G.A.; Anthemidis, A.N.; Stratis, J.A. Direct determination of toxic metals in honey and sugar using ICP-AES. Talanta 2005, 65, 92-97. [CrossRef] [PubMed]

13. Tiwari, P.; Naithani, P.; Tiwari, J.K. Determination of Heavy Metals in Honey Samples from Sub-Montane and Montane Zones of Garhwal Himalaya (India). World J. Pharm. Pharm. Sci. 2016, 5, 812-819. [CrossRef]

14. Alghamdi, A.H. Applications of stripping voltammetric techniques in food analysis. Arab. J. Chem. 2010, 3, 1-7. [CrossRef]

15. Sanna, G.; Pilo, I.M.; Piu, P.C.; Tapparo, A.; Seeber, R. Determination of heavy metals in honey by anodic stripping voltammetry at microelectrodes. Anal. Chim. Acta 2000, 415, 165-173. [CrossRef]

16. Sochr, J.; Machková, M.; Machyňák, L'.; Čacho, F.; Švorc, L'. Heavy metals determination using various bismuth film modified carbon-based electrodes. Acta Chim. Slov. 2016, 9, 28-35. [CrossRef]

17. Pierini, G.D.; Pistonesi, M.F.; Di Nezio, M.S.; Centurión, M.E. A pencil-lead bismuth film electrode and chemometric tools for simultaneous determination of heavy metals in propolis samples. Microchem. J. 2016, 125, 266-272. [CrossRef]

18. Santos Nascimento, A.; Marchini, L.; Carvalho, C.; Araújo, D.; Silveira, T.; Olinda, R. Determining the Levels of Trace Elements $\mathrm{Cd}, \mathrm{Cu}, \mathrm{Pb}$ and $\mathrm{Zn}$ in Honey of Stingless Bee (Hymenoptera: Apidae ) Using Voltammetry. Food Nutr. Sci. 2015, 6, 591-596. [CrossRef]

19. Vladislavić, N.; Rončević, I.Š.; Buzuk, M.; Buljac, M.; Drventić, I. Electrochemical/chemical synthesis of hydroxyapatite on glassy carbon electrode for electroanalytical determination of cysteine. J. Solid State Electrochem. 2021, 25, 841-857. [CrossRef]

20. Malmberg, P.; Bigdeli, N.; Jensen, J.; Nygren, H. Formation of hydroxyapatite on titanium implants in vivo precedes boneformation during healing. Biointerphases 2017, 12, 041002. [CrossRef]

21. Nygren, H.; Bigdeli, N.; Ilver, L.; Malmberg, P. Mg-corrosion, hydroxyapatite, and bone healing. Biointerphases 2017, $12,02 \mathrm{C} 407$. [CrossRef]

22. Skwarek, E.; Janusz, W.; Sternik, D. The influence of the hydroxyapatite synthesis method on the electrochemical, surface and adsorption properties of hydroxyapatite. Adsorp. Sci. Technol. 2017, 35, 507-518. [CrossRef]

23. Kanchana, P.; Sekar, C. Development of electrochemical folic acid sensor based on hydroxyapatite nanoparticles. Spectrochim. Acta Part A Mol. Biomol. Spectrosc. 2015, 137, 58-65. [CrossRef] [PubMed]

24. Koch, C.F.; Johnson, S.; Kumar, D.; Jelinek, M.; Chrisey, D.B.; Doraiswamy, A.; Jin, C.; Narayan, R.J.; Mihailescu, I.N. Pulsed laser deposition of hydroxyapatite thin films'. Mater. Sci. Eng. C 2007, 27, 484-494. [CrossRef]

25. Sun, L.M.; Berndt, C.C.; Gross, K.A.; Kucuk, A. Material fundamentals and clinical performance of plasma-sprayed hydroxyapatite coatings: A review. J. Biomed. Mater. Res. 2001, 58, 570. [CrossRef]

26. Hamdi, M.; Hakamata, S.; Ektessabi, A.M. Coating of hydroxyapatite thin film by simultaneous vapor deposition. Thin Solid Films 2000, 377-378, 484. [CrossRef]

27. Sun, L.M.; Berndt, C.C.; Khor, K.A.; Cheang, H.N.; Gross, K.A. Surface characteristics and dissolution behavior of plasma-sprayed hydroxyapatite coating. J. Biomed. Mater. Res. 2002, 62, 228. [CrossRef]

28. Jin, B.; Shao, C.; Wang, Y.; Mu, Z.; Liu, Z.; Tang, R. Anisotropic Epitaxial Behavior in the Amorphous Phase-Mediated Hydroxyapatite Crystallization Process: A New Understanding of Orientation Control. J. Phys. Chem. Lett. 2019, 10, 7611-7616. [CrossRef]

29. Ramesh, S.; Tan, C.Y.; Hamdi, M.; Sopyan, I.; Teng, W.D. The influence of Ca/P ratio on the properties of hydroxyapatite bioceramics. In Proceedings Volume 6423, International Conference on Smart Materials and Nanotechnology in Engineering; International Society for Optics and Photonics: Bellingham, WA, USA, 2007; p. 64233A. [CrossRef]

30. Du, L.-W.; Bian, S.; Gou, B.-D.; Jiang, Y.; Huang, J.; Gao, Y.-X.; Zhao, Y.-D.; Wen, W.; Zhang, T.-L.; Wang, K. Structure of Clusters and Formation of Amorphous Calcium Phosphate and Hydroxyapatite: From the Perspective of Coordination Chemistry. Cryst. Growth Des. 2013, 13, 3103-3109. [CrossRef]

31. Rončević, I.Š.; Grubač, Z.; Metikoš-Huković, M. Electrodeposition of hydroxyapatite coating on AZ91D magnesium alloy for biomaterial application. Int. J. Electrochem. Sci. 2014, 9, 5907-5923.

32. Vladislavić, N.; Buzuk, M.; Brinić, S.; Buljac, M.; Bralić, M. Morphological characterization of ex situ prepared bismuth film electrodes and their application in electroanalytical determination of the biomolecules. J. Solid State Electrochem. 2016, 20, 2241-2250. [CrossRef]

33. Li, Y.; Liu, X.; Zeng, X.; Liu, Y.; Liu, X.; Wei, W.; Luo, S. Simultaneous determination of ultra-trace lead and cadmium at a hydroxyapatitemodified carbon ionic liquid electrode by square-wave stripping voltammetry. Sens. Actuators B Chem. 2009, 139, 604-610. [CrossRef]

34. Pan, D.; Wang, Y.; Chen, Z.; Lou, T.; Qin, W. Nanomaterial/Ionophore-Based Electrode for Anodic Stripping Voltammetric Determination of Lead:An Electrochemical Sensing Platform toward Heavy Metals. Anal. Chem. 2009, 81, 5088-5094. [CrossRef] [PubMed]

35. Pan, D.; Wang, Y.; Chen, Z.; Yin, T.; Qin, W. Fabrication and characterization of carbon nanotube-hydroxyapatite nanocomposite: Application to anodic stripping voltammetric determination of cadmium. Electroanalysis 2009, 21, 944-952. [CrossRef] 
36. Khan, A.A.A.; Abdullah, M.A. Bismuth-modified hydroxyapatite carbon electrode for simultaneous in-situ cadmium and lead analysis. Int. J. Electrochem. Sci. 2013, 8, 195-203.

37. El Mhammedi, M.A.; Achak, M.; Bakasse, M. Evaluation of a platinum electrode modified with hydroxyapatite in the lead(II) determination in a square wave voltammetric procedure. Arabian J. Chem. 2013, 6, 299-305. [CrossRef]

38. Mortada, W.I.; Kenawy, I.M.M.; Abdelghany, A.M.; Ismail, A.M.; Donia, A.F.; Nabieh, K.A. Determination of $\mathrm{Cu}^{2+}, \mathrm{Zn}^{2+}$ and Pb ${ }^{2+}$ in biological and food samples by FAAS after preconcentration with hydroxyapatite nanorods originated from eggshell. Mater. Sci. Eng. C 2015, 52, 288-296. [CrossRef]

39. Raizda, P.; Gautam, S.; Priya, B.; Singh, P. Preparation and photocatalytic activity of hydroxyapatite supported BiOCl nanocomposite for oxytetracyline removal. Adv. Mater. Lett. 2016, 7, 312-318. [CrossRef]

40. Boukamp, B.A. A Nonlinear least squares fit procedure for analysis of immittance data of electrochemical systems. Solid State Ion. 1986, 20,31-44. [CrossRef]

41. Macdonald, J.R. Impedance Spectroscopy: Emphasizing, Solid Materials and Systems; John Wiley \& Sons Inc.: New York, NY, USA, 1987; p. 301. ISBN 10:0471831220.

42. Shimizu, K.; Sepunaru, L.; Compton, R.G. Innovative catalyst design for the oxygen reduction reaction for fuel cells. Chem. Sci. 2016, 7, 3364-3369. [CrossRef] 